\title{
Food Security Governance in the Southeast Asia Region: from National to Regional Governance
}

\section{Zarządzanie bezpieczeństwem żywnościowym w Azji południowo-wschodniej: od zarządzania narodowego do regionalnego}

\section{- Abstrakt •}

Żywność stanowi podstawową potrzebę człowieka. Bez żywności trudno zaspokoić pozostałe potrzeby. Region Azji PołudniowoWschodniej, wraz z rosnącą populacją, degradacją środowiska naturalnego, a także negatywnymi konsekwencjami zmian klimatu i dynamicznego rozwoju gospodarczego, jest szczególnie narażony na jej brak. Celem artykułu jest analiza zmieniających się paradygmatów zarządzania bezpieczeństwem żywnościowym w regionie Azji Południowo-Wschodniej oraz identyfikacja szans i barier dla regionalnej współpracy w tym obszarze w ramach ASEAN. Analiza oparta została na założeniu, zgodnie z którym pojedyncze państwa nie są w stanie zapewnić sobie bezpieczeństwa żywnościowego samodzielnie, co czyni konieczną współpracę międzynarodową.

Słowa kluczowe: Azja Południowo-Wschodnia, zarządzanie regionalne, bezpieczeństwo żywnościowe

\section{- Abstract •}

Food constitutes the basic human need. Without food it is impossible to meet other needs. Southeast Asia - with its growing population, deteriorating environmental conditions, exposure to climate change and rapid economic development - is particularly exposed to its negative consequences. This analysis is based on the assumption that single states cannot achieve food security without some degree of international cooperation. The goal of the paper is to analyze the changing paradigms of food security governance in Southeast Asia and identify opportunities and constraints to regional food security governance in the ASEAN context.

Keywords: Southeast Asia, regional governance, food security 


\section{Introduction}

Since the time of Thomas Malthus, there has been a constant debate how to achieve food security worldwide. Despite immense technological progress, the eradication of hunger is still a distant goal. The statistics are alarming. According to FAO estimates, almost one-sixth of humanity suffers hunger (FAO, 2009). It is interesting that the problem of food insecurity is not in the amount of food or food production, because the problem remains unsolved even though food production has begun to exceed the needs of the growing world population. It has become clear that food insecurity is not caused by the lack of food per se but has deeper roots.

This paper is based on the general assumption that under the globalization processes single states cannot achieve food security without some degree of international cooperation. Even though states are considered primary actors, the multidimensional character of factors influencing food security makes multilevel cooperation necessary. The example of the European Union (EU), which was able to transform itself from net-importer to net-exporter of food due to its Common Agriculture Policy, proves the benefits of regional cooperation in the agricultural sector.

Food security poses a special challenge in the Southeast Asia region. With its growing population, deteriorating environmental conditions, exposure to climate change, and rapid urbanization, the region is particularly exposed to negative consequences. Although the number of undernourished people has decreased considerably - according to the FAO in 2015 there were 61 million undernourished compared to 138 million in 1992 (FAO, 2015) future projections are not optimistic. According to the Consultative Group for International Agricultural Research (CGIAR), in the "Southeast Asia region with much of the population and infrastructure located in costal and river deltas, hundreds of millions of people are at great risk from the impacts of climate change, particularly sea level rise and climate/weather variability and greenhouse gas emissions" (CGIAR, 2016). What is more, growing urbanization makes it problematic to maintain the balance between the growing needs of urban dwellers and the agricultural sector.

The aim of the paper is to analyze the changing paradigms of food security governance in Southeast Asia and identify opportunities and constraints to regional food security governance in the ASEAN context. It is argued that close cooperation between states can contribute positively to assuring food security in the region. The shift from national to regional governance is not at the cost of nation states, however. It only illustrates the changing logic of problem-solving in new conditions. The multidimensional character of the food security problem requires 
a multi-actor approach. This means that nation-states can not assure food security on their own, yet on the other hand effective regional governance of food security is impossible without nation states.

The paper consists of three parts. The first briefly explains the concept of food security. Special attention is directed to new threats to food security, which make it necessary to look for multilateral governance mechanisms. The second concentrates on national food security governance and analyzes its limits from a theoretical as well as an empirical point of view. The third discusses the opportunities and constraints to regional food security governance in the ASEAN context.

\section{Food Security Concept}

The food security concept has been developed since the inception of the United Nations' Food and Agriculture Organization (FAO), but the need for some form of multilateral food security arrangements had already been recognized by the League of Nations before the Second World War (Shaw, 2007). Despite the fact that its content has changed over the six decades of the FAO's existence, the idea which laid behind its development was still the same. It was not about food per se but the fulfillment of one of the basic human needs.

There are about two hundred definitions of food security nowadays (FAO, 2003). The most influential and universally accepted one is the definition the FAO adopted at the 1996 World Food Summit: "food security, at the individual, household, national, regional and global levels is achieved when all people, at all times, have physical and economic access to sufficient, safe and nutritious food to meet their dietary needs and food preferences for an active and healthy life" (FAO, 2003). The definition was revised in 2001; in addition to physical and economic access, a new, social, dimension was added (FAO, 2003). The current FAO definition divides food security into four dimensions: physical availability of food, where production and distribution are involved; economic and social access, where issues of poverty reduction and food prices play the most important role; the stability of access which means undisturbed access; and food utilization which covers the issues of the proper quality of food and food safety (Teng, Lassa, 2016).

Similar to the evolution of the food security concept has been evolution of threats to it. Discussion about it has a long tradition. In the $17^{\text {th }}$ century Thomas Malthus drew attention to the direct connection between demographic factors and hunger. He argued that population when unchecked increases at a geometric ratio, but the production of food increases in only an arithmetic ratio. This 
inevitably leads to a situation of world starvation. Malthus, however, reached his conclusions in a specific historical context, and he could not anticipate the application of technological advances in future food production, which softened the pessimistic character of his prognosis.

Four groups of threats to food security can currently be identified (MarzędaMłynarska, 2014). The first consists of natural factors that affect food production and the livelihoods of small subsistence farmers: land, water and weather. All have a finite nature and cannot be replaced by other factors. In the case of land, the problem is not only its finite character, but, more importantly, unequal distribution between states. The available resources of arable land are located in countries that either do not have sufficient means to use it (Sub-Saharan Africa, Latin America) or do not find themselves under pressure to increase crop production (Russia). This situation leads to the "land-grabbing" practice that, in brief, can be described as a growing competition between states to secure access to arable land outside their territory through acquisitions or leasing. It is not a coincidence that the top "land-grabbers" include China, India, Saudi Arabia, South Korea and UAE. The same can be said about water. Since agriculture is the biggest "consumer" of fresh water, limited access to it poses a growing threat to food security. The increasing "water deficit" is treated as the biggest impediment influencing future food production. The third factor that influences production is weather. Increasing weather unpredictability due to climate change makes agricultural production subject to higher risks of droughts, floods, hurricanes and other extreme weather conditions. As Josef Schmidhuber and Francesco N. Tubiello argue, climate change affects food production directly through changes in agro-ecological conditions and indirectly by affecting growth and distribution of incomes and thus the demand for agricultural produce (Schimidhuber, Dubiello, 2007). Projections show that the land suitable for wheat production may almost disappear in Africa due to climate change (von Braun, 2007). As a result, agricultural prices will also be affected by climate change. Temperature increases of more than 3 degrees Celsius may cause prices to increase by up to 40 percent (Esterling et al., 2007).

The second group of threats to food security consists of economic factors. These include growing food prices as well as changes in income distribution. The negative experiences of the 2008 financial crisis contributed to changing patterns of financial investment behavior. Investors became more interested in investing in more "secure" sectors such as agriculture, since the demand for food will never end. This new trend, fueled by information about shortages in supply caused by weather conditions in Russia and Australia, contributed to food price spikes in 2010 and 2011. Part of the problem is biofuels production. The rising price of fossil 
fuels (oil, gas), accompanied by the shift towards more ecological energy sources, has increased the use of agricultural products for industrial purposes dramatically. According to FAO estimates, the use of cereals for biofuels production has increased by more than 25 percent (von Braun, 2007). Paradoxically, the income growth which should be perceived as a means to eradicate poverty is also considered as a threat to food security. High income growth in countries such as China and India readily translates into changing patterns of food consumption. The shift from the consumption of grains and other staple crops to meat, dairy and fish resulted in agricultural diversification toward high value agricultural production. The growing demand for high-value products is satisfied at the cost of the poorest whose access to this kind of food is limited.

The third group of threats consists of social factors. It includes population growth and rapid urbanization. Existing prognoses indicate that population growth will have a significant impact on food security in the near future. Two negative consequences can be identified. First, the growing number of people will have a profound impact on food availability. More people means higher demand for food, more food production means greater pressure on crops. More crops means growing competition over resources such as land and water. Even though existing prognoses differ about the number of people the Earth can feed (from 13 billion to one trillion; Müller, 2011; Waterlow et al., 1998; Leisinger et al., 2002), it is impossible to sustain current consumption patterns. Second, growing populations will negatively affect access to food. Because the highest population growth rates characterize the poorest states, it will be very hard for them to fight poverty and enter the path of economic development. More people means growing demand on food, but also housing, education and health care. It is also accompanied by rapid urbanization. It is said that the $21^{\text {st }}$ century will be the century of urbanization, with projections that two-thirds of humanity will be living in towns and cities by 2050 compared with one-third in 1960 (Caballero-Anthony, Teng, Escaler, 2011). The result will be a shrinking pool of arable land due to the expanding settlements on the one hand, and the problems of supplying food to a growing urban population on the other (Caballero-Anthony, Teng, Escaler, 2011).

In the fourth group there are threats posed by globalization processes that influence the production and distribution of food worldwide and the structure of global food markets. As Paul Teng et al. indicate, "The twentieth century saw the growing consolidation of food and agriculture corporations... [which] control ever larger portions of the food supply, inputs, technology, and value chains and use their size and influence to generate favorable conditions to maximize their profits" (Teng, Lassa, 2016). The industrialization of agriculture, the growing role 
and importance of food and agricultural transnational corporations, changes in the corporate food system, the monopolization of biotechnological improvements in agriculture due to the application of property rights, and the hypocrisy of liberalization of international trade in agriculture, all can be identified as its main manifestations.

\section{National Food Security Governance and Its Limits}

The food security concept brought a new perspective to the issue of world starvation. The identification of its four dimensions make the problem of food security governance extremely difficult. What is more, current international practice shows that, due to the broad character of food security, the actions to achieve it are taken in different policy areas, e.g. agriculture policy, trade policy, development policy and food safety policy. It must be pointed out that the contradictory character of food security goals makes these efforts less effective.

Debate on food security governance was stimulated by two important events: the 1996 World Food Summit and food crises from 2008 and 2011. Two general opinions on food security governance can be identified. The first emphasizes the need to return to national food security governance, while the second, conversely, emphasizes the need of more regional or global food security governance.

The first "school" is represented by Robert Paarlberg, who argues that food insecurity in developing states, manifested in the extreme forms by hunger and malnutrition, is due to the lack of proper governance at the national level (Paarlberg, 2002). His arguments can be summarized as follows: states are the primary actors responsible for providing food security to their citizens, all necessary instruments needed to achieve food security are located at the national level: including food and agriculture policies, subsidies and support to local producers, trade instruments, and national governments still play the dominant role in food production. While not a direct role, states also affect food production by delivering domestic public goods such as peace, the rule of law, public research and infrastructure (Paarlberg, 2002). The failure to deliver these, which is characteristic of all poor food insecure states, contributes to chronic hunger and malnutrition, yet governance deficits and failures at the national level are responsible for the persistence of hunger in many regions.

To some extent, Paarlberg is right. Indeed, in most developed countries, including the EU with its Common Agriculture Policy, national governments transfer lots of money to local food producers in the form of direct and indirect sup- 
port, but this is not the case in most of the countries affected by chronic food insecurity. Important external factors can be identified that make national food security governance extremely hard, e.g., international trade. Violations, distortions and speculation in the global food market can easily worsen food security in many countries, especially those depending on food imports. According to statistics, seven of the world's ten largest food importers are developing countries (Rediff Business, 2012). A dramatic rise of food staples prices even caused riots in developed countries like Italy in 2008. The 2011 "Arab spring" was also motivated by increases in food staples prices. Those events have exposed the weaknesses of national level governance in preventing food insecurity and proved the lack of suitable instruments to deal with the external forces that influence it: market mechanisms, transnational corporations and the policies of food exporting states.

While national governments are undeniably the primary actors responsible for assuring food security at the state level, there are limits to national food security governance stemming from factors influencing food production, distribution and consumption. They can be divided into four groups: internal, external, objective and subjective.

Internal factors have their roots in the state's capacity and institutional effectiveness. Weak governments, lack of infrastructure and human capital, underdevelopment and poverty, and internal conflicts negatively affect food production, distribution and consumption. Most food insecure states are at the same time politically unstable and mired in conflicts. The government's inability to fulfill its functions can be explained by Thomas Risse's theory of limited statehood. It is based on the belief that the idea of a modern and consolidated nation-state with a full monopoly over the means of violence and the capacity to effectively enforce central decisions only describe a very narrow group of highly developed countries (Risse, 2012). "Outside the OECD world, there are areas of «limited statehood» including developing and transition countries to failing and failed states" (Risse, 2012). These areas lack the capacity to implement and enforce central decisions and a monopoly on the use of force.

External factors have their roots outside the country and consist of trade agreements, International Financial Institution policies and transnational corporations' activities. The Uruguay Round Agreement on Agriculture brought agricultural trade more fully under international regulations. In developed countries these regulations did not necessarily mean barriers to national food governance, but for most developing countries they sharply limited room for maneuver. $\mathrm{Na}-$ tional food security governance is also strongly limited by International Financial Institution policies and programs (conditionality). Contrary to Paarlberg's argu- 
ments, countries where food insecurity is the most severe deregulated their food sectors under the IFI pressure. Since the introduction of Structural Adjustment Programs, many ended public support of local farmers, fixed food prices and subsidies for food, and opened their markets to food imports. This kind of policy only deepened the dependence of the poorest countries on global markets and price violations, and made local production uncompetitive and unprofitable.

TNC activities in food and agriculture governance is also very important in this context. This impact is twofold. On the one hand, corporations monopolize the global food production, distribution and consumption chain. They produce only profitable foods at the expense of staples, like grains. Their production even in poor and developing countries is focused on export, so locals do not benefit from it. TNCs control most agricultural technologies and strongly use property rights to strengthen their position in global markets. According to the 2005 report of the Erosion, Technology and Concentration Group, the top ten seed companies controlled nearly $50 \%$ of the US \$ 21 billion annual global commercial seed market and nearly all of the genetically engineered seed market, the top ten pesticide companies controlled $84 \%$ of the US \$ 30 billion annual pesticide market, and finally, the ten top food retailers controlled $24 \%$ of the estimated US \$ 3.5 trillion global food market (Clapp, Fuchs, 2009). At the same time, TNCs are major players in international regulations on food production. The FAO/WHO Codex Alimentarius, established in 1963 as an international body responsible for food safety and quality standards, is a good example of this problem. Over the years its decision-making processes were dominated by TNCs, which used them to legitimize standards, definitions and composition of their own products (Krut, 1997). According to data on the participants in the Codex Alimentarius Commission sessions between 1989-1991, in the twelve specialized committees in which deliberations were held, there were 105 country representatives and 140 representatives of food and agriculture corporations. Nestle had 38 representatives, more than most countries. Overall, corporate representatives amounted to $35 \%$ of the total of the ten largest national delegations and as much as $22 \%$ of all participants (Avery et al., 1993).

Objective factors consist of geographical factors that are outside governmental control as well as globalization processes ${ }^{1}$. Food production depends on availability and quality of land and water, yet these resources are unevenly distributed among states. The same can be said for states' locations - coastal areas, depres-

${ }^{1}$ It should be emphasized, however, that there is no consensus on whether globalization is an objective or subjective process. 
sions, deserts, climate - suitable for farming or not, or the prevalence of endemic diseases. The striking example of the objective factors that undermine the effectiveness of national food security governance is climate change, something that cannot be effectively controlled by single states.

Wolfgang Reinicke's theory sheds some light on the limits to national governance conditioned by globalization processes. In an analysis on globalization's impact on states' policy, he has distinguished two forms of sovereignty: external, which constitutes the central rule of the international system and refers to the mutual exclusivity of states operating in the anarchic world system, pursuing their own interests, and internal, which can be understand as the ability to formulate, implement and manage internal public policy (Reinicke, 1998). Reinicke believes globalization processes pose a fundamental challenge to internal sovereignty. The limitation of nation states' ability to govern their internal affairs is due to changes in "political geography" and "economic geography" (Coleman, 2012). States' internal sovereignty is limited by their territory, but at the same time internal affairs, like economic well-being, are increasingly affected by external forces (global markets, transnational trade relations, TNCs), which cannot be effectively controlled by states' governments and their instruments. Food security, which strongly depends on localized factors outside the states, is one example of problems that should be addressed at different levels. This does not mean, however, that nation states should be excluded from new forms of governance. The national level still plays an important role in food security governance.

Subjective factors include ideologies, cultures, religions, mentalities, value systems and traditions, which can in certain circumstances positively as well as negatively influence national food security governance. The government's attitude about effectively fighting hunger and poverty, the content of food policies and food related policies can be strongly influenced by those factors and work in favor of vulnerable populations or against their interests.

The second "school" within the debate on food security governance concentrates on higher-than-national levels of governance. It is based on an assumption that the only way to assure food security worldwide is to increase international cooperation and strengthen international institutions. This way of thinking was present after World War II and reflected in the establishment of the FAO. Coordination and cooperation at the international level were recognized as mechanisms that could have a positive impact on resolving the problem of hunger and malnutrition. The same way of thinking inspired the European Union's Common Agriculture Policy. Integration of agricultural policies within the EU was perceived as not only a way to achieve higher equality of incomes in agriculture and industry 
but also as a way to prevent EU countries from starvation. Thus, regional governance can play a positive role in assuring food security at the national level.

Saidul Islam and Iris Carla de Jesus identify five arguments in favor of a regional approach to food security. First, regional initiatives can prevent price volatility transmitting on the national level through regulation of the regional food market. Second, regional approaches to food security can significantly reduce the influence of big transnational companies on food distribution and prices. Regional markets, if created, can better serve the needs of the population than private companies can. Third, the regional level is better suited to create regional food security sector governance frameworks, where all stakeholders can participate despite their location, which can have a positive impact on food security. Fourth, regional initiatives can better target vulnerable and excluded communities such as minorities, refugees, etc. Fifth, regional initiatives allow for better targeting of food resources in situations of changing food consumption patterns and declining agriculture investments (Islam, Jesus, 2012).

Southeast Asia is a region with many reasons to be food secure. It has favorable climate, good soils and access to water, yet still 60 million people are food insecure. Even though the states in the region have made huge progress and considerably reduced the number of hungry and undernourished people, they face new challenges to their food security such as changed food consumption patterns, increased reliance on imports and rapid urbanization. As Belinda Chng points out, "Consequently, they [states] may be left with no choice but to seek regional or multilateral options to complement their own food strategies" (Chng, 2013). She identifies two factors that can pose limits on national food security governance. First, the growing exposure to supply distortions and price volatility due to growing import of food (wheat) and animal feed (corn, soybeans) stimulated by changes in consumption. Second, the increased demand for food due to rapid demographic growth, especially in Indonesia, Malaysia and Thailand (Chng, 2013). Two more factors should be added, however: the decreasing pool of arable land due to rapid urbanization and the rising vulnerability to changing climate. The last factor, especially, will affect future food security in the region. According to a report by the Climate Emergency Institute, climatic disasters such as floods, droughts, cyclones, typhoons and tsunamis are responsible for major food supply losses in Southeast Asia through the destruction of existing crops, decline in yields and rising seawater acidity (Climate Emergency Institute, 2012). These factors cannot be fully controlled by governments, pose limits to national food security governance and make regional cooperation necessary. 


\section{Chances and Constraints to the Regional Food Security Governance in the ASEAN Context}

In the literature, we can find different definitions of "regional governance" (Higgot, 2005; Stuchlíková, Hnát, 2007; Risse, 2015; Börzel, 2015). Basically, these depend on the way "region" and "governance" are defined. In this paper, "region" will be understood as a "supranational unit of governance that is not a state but has some statehood properties" (van Langenhove, 2012) and "governance" as a specific form of international decision-making (Marzęda-Młynarska, 2014) in which "substance lies in a more efficient involvement of various levels of decisionmaking in opposition to almost exclusive role of national state" (Stuchlíková, Hnát, 2007). Thus, regional governance will be defined as a "multi-dimensional set of institutions that are able to answer regional challenges, where «regional level» represents arrangements between individual nation-states, is not dominated by regional institution and involve a combination of the policy-making mechanisms that are located at regional and state level" (Stuchlíková, Hnát, 2007). Regional food security governance consists of three elements: institutional, normative and functional, and can be treated as a part of existing regional arrangements or as regional coordination processes detached from existing regional bodies.

Two complementary visions of food security governance exist in Southeast Asia. The first is national food security governance treated as a part of a broader framework aimed at fighting poverty. As Islam and de Jesus point out, "The countries in [the region] have adopted a number of policies and programs aimed at (...) food insecurity, both on their own initiative and as a result of pressure to promote better programs and food polices" (Islam, Jesus, 2012). The 2007/2008 food crisis revealed the ambiguity of national policies in achieving regional food security, however. While some countries benefited from rising rice prices by selling surplus on the global market, e.g. Thailand and Vietnam, others such as the Philippines faced a rapid deterioration of their food security. "Seeking greater economic gain from the rise of international food prices during the food crises, key rice producing countries in the region chose to supply global food needs at the expense of fulfilling the needs of other ASEAN member countries" (Chandra, Lontoh, 2010). What is more, in the face of growing dependence on food imports, demographic pressure and exposure to climate change, the national food security governance has reached its limits.

The second vision of food security governance - regional - supplements the national approach by addressing issues which cannot be effectively dealt with at 
the national level. Regional governance does not substitute national governance, however, but rather constitutes an area where regional priorities can be addressed. Closer cooperation at the regional level can contribute positively to food availability, access and stability by accelerating trade, creating food reserves, or in general accelerating economic growth through closer integration. While it is impossible to adopt a common ASEAN agriculture policy based on the EU model, there is a broad space within ASEAN for closer cooperation in other ways in the food security area.

ASEAN and ASEAN Plus Three represent the institutional dimension of Southeast Asian regional food security governance. ASEAN was created in 1967 in the common desire to create a platform for regional cooperation based on similar goals and purposes. These include: facilitating the acceleration of economic growth, social progress and cultural development; promoting regional peace and stability; and active collaboration in different fields. As a regional structure ASEAN addresses the "internal" dimension of regional food security by offering its member states a forum where regional as well as national interests can be fulfilled. It consists of two governance mechanisms: ASEAN regulations on trade, services, and investments that indirectly address the problem of food security, and initiatives designed to target food security directly.

The ASEAN Plus Three (APT) addresses the external dimension of regional food security. The process was initiated in 1997 and includes cooperation between ASEAN and China, Japan and South Korea in the areas of politics and security, economics and finance, environment and climate change, and socio-cultural and development. Food security as a part of the economic and finance area represents an issue of high interest as evidenced by concrete initiatives.

The normative dimension of ASEAN regional food security governance is addressed by the ASEAN Economic Community Initiative, which is treated as both a necessary impetus for intraregional food trade and a mechanism facilitating flow of staples such as rice from "surpluses states" to "shortages" ones (Teng et al., 2015). Its aim is to improve the effectiveness of regional supply chains through tariff reduction, simplifying border procedures, reducing the cost of transportation, ensuring food safety (standards harmonization) and enhancing infrastructure.

The functional dimension of ASEAN regional food security includes concrete initiatives addressing food security. It should be emphasized, however, that food, agriculture and forestry have been an area of special ASEAN interest since 1993, when the ASEAN Ministers of Agriculture and Forestry identified "strengthening food security in the region" as the first of the seven areas of cooperation in that sector. Three initiatives play key roles in regional food security governance: first, ASEAN Integrated Food Security Framework (AISF) and the Strategic Plan of 
Action on Food Security, 2015-2020, which seeks to sustain increased food production, promote conducive markets and trade for agricultural commodities and inputs, and ensure food supply stability to improve the livelihoods of farmers and ensure long-term food security and nutrition (FAO, 2015). Second, the ASEAN Plus Three Emergency Rice Reserve (APTERR) and third, the ASEAN Food Security Information System. Both AIFS and APTERR were ASEAN's responses to the 2007/2008 food crisis.

The fundamental goal of the AIFS Framework is to "improve and support the livelihoods of farmers and to ensure regional food security over the long term" (Belesky, 2014). The ASEAN leaders pledged at the $14^{\text {th }}$ ASEAN Summit in Thailand in 2009 to embrace food security as high priority policy and to review ASEAN's commitment to the objectives of the World Food Summit and the MDGs. They have adopted the ASEAN Integrated Food Security Framework and the Strategic Plan of Action on Food Security in ASEAN. The AIFS Framework consists of five components and nine strategic thrusts. The first component concerns food security emergency/shortage relief and consists of one thrust, to strengthen food security arrangements. The second component is devoted to sustainable food trade development and consists of one thrust, to promote conducive food markets and trade. The third component concerns the integrated food security information system and consists of one thrust, to strengthen Integrated Food Security System. The fourth component is devoted to agro-innovations and consists of three thrusts: promoting sustainable food production, encouraging greater investment in food and agro-based industry, and identifying and addressing emerging issues. The fifth component is devoted to nutrition-enhancing agricultural development and consists of three thrusts: utilizing nutrition information to support evidencebased food security and agriculture policies, indentifying policies and governance mechanisms for nutrition-enhancing agricultural development, and, third, to develop and strengthen nutrition-enhancing agriculture policies/programs and build capacity for their implementation, monitoring and evaluation (ASEAN, 2014).

The ASEAN Plus Three Emergency Rice Reserve was approved in 2009 and became operational in 2012. The idea of regional food reserves is based on the assumption that storage of staple foods which "have sociopolitical and economic significance and are culturally appropriate in particular region - rice in Asia" (Belesky, 2014) is critical to food security and especially food availability. Food reserves are treated as a governance tool especially in emergency or crisis situations. Under the current initiative, thirteen countries have pledged to make a total of 787 thousands of tons of rice available in case of instability in the supply or production due to conflicts, natural disasters and calamities (Belesky, 2014). 
The above mentioned initiatives are supplemented by the ASEAN Food Security Information System (AFSIS), established in 2002 by the Ministers of Agriculture and Forestry of the ASEAN member states plus China, Japan and Korea. It was designed to strengthen food security in the region through systemic collection, analysis and dissemination of food security related information. It was divided into phases. The first took place from 2003 to 2007 and was devoted to enhancing the regional food security information system and increasing the capacities of member states in providing required information. The second was designed for five years, from 2008 to 2012, and extended to three elements: Early Warning information, Agricultural Commodity Outlook and Technical Cooperation (AFSIS, 2016).

The EU example shows that close regional cooperation in agriculture can bring positive results, such as assuring food security and independence from food imports. While it is impossible to replicate the EU patterns, ASEAN, through its regional initiatives, proved to have great potential to become food secure and build sound regional food security governance. What is more, the shift from national to regional food security governance can be observed in the ASEAN context, although it is still far from fully integrated regional food security governance.

The problem of states' readiness to shift decision-making power to a higher level (regional or global) has been discussed since the 1970s. In the early works on this issue (Cox, Jacobson, 1973), it was argued that states are only willing to transfer part of their authority to a higher level if the relevant problems were technical in nature, were not politicized and did not touch upon their interests. When it comes to food security, the problem is embedded in a socio-economic and political nexus that makes it a very complicated and sensitive issue for nation states. There is, however, another second side of the coin. The increasingly transnational character of threats to food security makes regional cooperation essential. The interplay between national and regional food security governance in the ASEAN context can be assessed through identification of its opportunities and constrains.

Opportunities for regional food security governance. Objectively, ASEAN is a food surplus region but with seasonal and spatial food insecurity in certain countries/areas. The enhancement of regional governance could improve food distribution among ASEAN member states and help avoid seasonal food shortages. The next argument for closer cooperation is localization. All ASEAN members are located in an area that makes them equally exposed to the consequences of climate change, especially extreme weather conditions. Regional food security governance can provide them with "food insurance" in case of natural catastrophes or calamities. What is more, due to rapid urbanization and demographic growth, some 
countries will face supply problems while others are able to increase production of staples such as rice. The divide between surplus and shortage countries can work as an argument for closer economic integration and creation of a common food market. The completion of the ASEAN Economic Community project and building a real single market can be treated as the biggest opportunity to enhance regional food security governance as well as assure food security in the region.

Constraints to regional food security governance. The existential character of food security makes it a highly political issue. States are not inclined to relinquish their authority over certain issues when they touch national security and survival. Food insecurity at the beginning of the $21^{\text {st }}$ century poses threats not only to human security but also traditional security. A World Bank prognosis suggests that within the next 15 years, the world could face food wars (The Guardian, 2014). The perception of food insecurity as a threat to national security makes unilateral solutions more attractive. Relying on an external mechanism especially trade, proved ineffective in the face of the 2007/2008 food crisis, when import-dependent states were not able to satisfy their needs. Many of them have changed their food policy and switched from food imports to production of food abroad (buying or leasing large land in other countries). What is more, the strong attachment to the state sovereignty within ASEAN makes all attempts to create a regional food policy similar to the European Union's CAP unlikely. This is due not only to the prevailing conviction of ASEAN member states that national governance is critical to achieve food security, but also to the contradictory interests of their national food and agriculture policies. The key factor for the further development of regional food security governance remains the level of political will of ASEAN member states.

\section{Conclusions}

This paper was devoted to an analysis of the changing paradigms of food security governance in Southeast Asia. It was based on an assumption that due to the "transnational" character of factors influencing food security, single states cannot achieve it without some degree of international cooperation. Its goal was to identify the opportunities and constraints to regional food security governance in the ASEAN context.

Three general conclusions can be formulated. First, a steady shift from national to regional food security governance in Southeast Asia can be observed; however, regional arrangements are treated as supplements not substitutes for national ones. 
Second, while national governance is recognized as the key to achieve food security at the national level, its impact on regional food security is ambiguous. The completion of the ASEAN Economic Community Initiative and building a real single market can be an answer to the contradictory interests of surplus and shortage states.

Finally, opportunities and constraints to ASEAN food security governance can be identified. While objective factors - food production potential, lack of food distribution channels within the region and equal exposure to climate change make regional solutions necessary, the progressive "securitization" of food security and its existential character incline states toward greater reliance on unilateral solutions such as the production of food abroad.

\section{References:}

AFSIS. (2016). About Us. Derived from: http://www.afsisnc.org/aboutus.

ASEAN. (2014). ASEAN Integrated Food Security (AIFS) Framework and Strategic Plan Of Action on Food Security in the ASEAN Region. Derived from: http://www.asean-agrifood.org/download/asean-integrated-food-security-aifs-framework-and-the-strategicplan-of-action-on-food-security-in-the-asean-region-spa-fs/.

Avery, N., Drake, M., Drake, T. (1993). Cracking the Codex: An Analysis of Who Sets World Food Standards. London.

Belesky, P. (2014). Regional Governance, Food Security and Rice Reserves in East Asia. Global Food Security, 3, 167-173.

Börzel, T. (2015). Theorizing Regionalism: Cooperation, Integration, and Governance. In: T.A. Börzel, T. Risse (eds.), Oxford Handbook of Comparative Regionalism. Oxford: Oxford University Press.

Caballero-Anthony, M., Teng, P., Escaler, M. (2011). Urban Food Security: Feeding Tomorrow's Cities. Significance, 8 (2), 57-60.

CGIAR. (2016). Southeast Asia. Derived from: https://ccafs.cgiar.org/regions/southeastasia.

Müller, Ch., et al. (2011). Towards a Great Land-Use Transformation?. In: H.-G. Brauch et al. (eds.), Coping with Global Environmental Change, Disasters and Security. Threats, Challenges, Vulnerabilities and Risks. Berlin - Heidelberg: Springer.

Chandra, A.C., Lontoh, L.A. (2010). Regional Food Security and Trade Policy in Southeast Asia. The Role of ASEAN, IISD, TKN. Series on Trade and Food Security, Policy Report 3. Winnipeg, Manitoba.

Chng, B. (2013). Southeast Asia's Food Security Challenge: More than 'Stock' Solution Needed. Derived from: http://reliefweb.int/report/world/southeast-asia\%E2\%80\%99sfood-security-challenge-more- $\% \mathrm{E} 2 \% 80 \% 98$ stock $\% \mathrm{E} 2 \% 80 \% 99$-solution-needed.

Clapp, J., Fuchs, D. (2009). Agrifood Corporations, Global Governance, and Sustain- 
ability: A Framework for Analysis. In: J. Clapp., D. Fuchs (eds.), Corporate Power in Global Agrifood Governance. London: The MIT Press.

Climate Emergency Institute. (2012). Impact of the Global Warming on Food Security in Southeast Asia. Derived from: http://www.climateemergencyinstitute.com/uploads/ IMPACT_OF_GLOBAL_WARMING_ON_FOOD_SECURITY_OF_SOUTH_ EAST_ASIA.pdf.

Climate Change Will 'Lead to Battles For Food', Says Head of World Bank. (2014). Derived from: https://www.theguardian.com/environment/2014/apr/03/climate-change-battlefood-head-world-bank.

Coleman, W.D. (2012). Governance and Global Public Policy. In: D. Levi-Faur (ed.), The Oxford Handbook of Governance (p. 673-685). Oxford: Oxford University Press.

Cox, R.W., Jacobson, H.K. (eds.). (1973). The Anatomy of Influence. Decision-making in International Organization. New Haven, CT: Yale University Press.

Easterling, W.E. et al. (2007). Food, fibre and forest products. In: M.L. Parry, O.F. Canine, J.P. Palutikof, P.J. van der Linden, C.E. Hanson (eds.), Climate Change 2007: Impacts, Adaptation and Vulnerability. Contribution of Working Group II to the Fourth Assessment Report of the Intergovernmental Panel on Climate Change (p. 273-313). Cambridge: Cambridge University Press.

FAO. (2015). The State of Food Insecurity in the World 2015. Rome.

FAO. (2003). Trade Reforms and Food Security. Conceptualizing the Linkages. Derived from: ftp://ftp.fao.org/docrep/fao/005/y4671e/y4671e00.pdf.

FAO. (2009). More People Then Ever Are Victims of Hunger. Derived from: http://www. fao.org/news/story/en/item/20568/icode/>.

Higgott, R. (2005). The Theory and Practice of Global Regional Governance: Accommodating American Exceptionalism and European Pluralism. GARNET Working Paper, no 01/05.

Islam, S., De Jesus, I.C. (2012). Regional Initiatives on Food Security. In: R. Rayfuse, N. Weisfelt (eds.), The Challenge of Food Security. International Policy and Regulatory Frameworks (p. 255-274). Cheltenham, UK, Northhampton, MA, USA: Edward Elgar.

Krut, R. (1997). Globalization and Civil Society: NGO Influence in International Decision-Making. UNRISD Discussion Paper, no 83.

Leisinger, K.M. et al. (2002). Six Billion and Counting. Population Growth and Food Security in the 21st Century. Washington DC: IFPRI.

Marzęda-Młynarska, K. (2014). Globalne zarządzanie bezpieczeństwem żywnościowym na przełomie XX i XXI wieku. Lublin: Wydawnictwo UMCS.

Paarlberg, R.L. (2002). Governance and Food Security in an Age of Globalization. IFPRI Discussion Paper, 36.

Rediff Business. (2012). World's Top 10 Exporters and Importers of Food. Derived from: http://www.rediff.com/business/slide-show/slide-show-1-worlds-top-10-exportersand-importers-of-food/20110315.html.

Reinicke, W. (1998). Global Public Policy: Governing without Government?. Washington DC.

Risse, T. (2012). Governance in Areas of Limited Statehood. In: D. Levi-Faur (ed.), The Oxford Handbook of Governance (p. 699-715). Oxford: Oxford University Press. 
Risse, T. (2015). The Diffusion of Regionalism, Regional Institutions, Regional Governance. Paper presented at the EUSA 2015 Conference, Boston, USA, March 5-7, 2015.

Schimidhuber, J., Dubiello, F.N. (2007). Global Food Security under Climate Change. Derived from: www.pnas.org_cgi_doi_10.1073_pnas.0701976104.

Shaw, D. J. (2007). World Food Security. A History Since 1945. New York: Palgrave Macmillan.

Stuchlíková, Z., Hnát, P. (2007). Regionalism as a Part of Regional Governance: Europe and South-East Asia. Faculty of International Relations Working Papers, no 3.

Teng, P., et. al. (2015). Towards Asia 2025: Policy and Technology Imperatives. Summary of the Main Findings of the Second International Conference on Asian Food Security Held Singapore on 21-22 August 2014, Conference Report. "Food Security", 7, 159-165.

Teng, P., Lassa, J. (2016). Food Security. In: M. Caballero-Anthony (ed.), An Introduction to Non-traditional Security Studies. A Transnational Approach (p. 114-133). London: Sage.

Van Langenhove, L. (2012). Why We Need to "Unpack" Region to Compare Them More Effectively. The International Spectator. Italian Journal of International Affairs, 47(1), $16-29$.

Von Braun, J. (2007). The World Food Situation. New Driving Forces and Required Actions. Washington: IFPRI Food Policy Report.

Waterlow, J.C., et al. (eds.). (1998). Feeding a World Population of a More Than Eight Billion People. New York - Oxford: Oxford University Press. 